INTERNATIONAL
International Center for Public Policy

Working Paper 20-01

February 2020

\title{
Trust in Government Institutions and Tax Morale
}

Antonios M. Koumpias

Gabriel Leonardo

Jorge Martinez-Vazquez

\section{ANDREWYOUNG SCHOOL}





\title{
$\underset{\substack{\text { Georgastate } \\ \text { University }}}{\iint_{0}} \mid \frac{\text { ANDREW YOUNG SCHOOL }}{\text { OF POLICY STUDIES }}$
}

\author{
International Center for Public Policy \\ Working Paper 20-01
}

\section{Trust in Government Institutions and Tax Morale}

\author{
Antonios M. Koumpias \\ Gabriel Leonardo \\ Jorge Martinez-Vazquez
}

February

2020

International Center for Public Policy

Andrew Young School of Policy Studies

Georgia State University

Atlanta, Georgia 30303

United States of America

Phone: (404) 413-0235

Fax: (404) 651-4449

Email: paulbenson@gsu.edu

Website: http://icepp.gsu.edu/

Copyright 2020, the Andrew Young School of Policy Studies, Georgia State University. No part of the material protected by this copyright notice may be reproduced or utilized in any form or by any means without prior written permission from the copyright owner. 


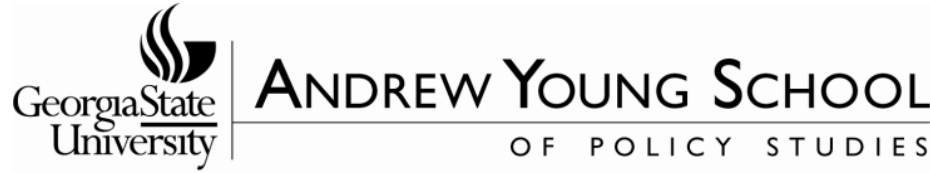

\section{International Center for Public Policy Andrew Young School of Policy Studies}

The Andrew Young School of Policy Studies was established at Georgia State University with the objective of promoting excellence in the design, implementation, and evaluation of public policy. In addition to two academic departments (economics and public administration), the Andrew Young School houses seven leading research centers and policy programs, including the International Center for Public Policy.

The mission of the International Center for Public Policy (ICePP) at the Andrew Young School of Policy Studies is to provide academic and professional training, applied research, and technical assistance in support of sound public policy and sustainable economic growth in developing and transitional economies.

ICePP is recognized worldwide for its efforts in support of economic and public policy reforms through technical assistance and training around the world. This reputation has been built serving a diverse client base, including the World Bank, the U.S. Agency for International Development (USAID), the United Nations Development Programme (UNDP), finance ministries, government organizations, legislative bodies, and private sector institutions.

The success of ICePP reflects the breadth and depth of its in-house technical expertise. The Andrew Young School's faculty are leading experts in economics and public policy and have authored books, published in major academic and technical journals, and have extensive experience in designing and implementing technical assistance and training programs. Andrew Young School faculty have been active in policy reform in over 40 countries around the world. Our technical assistance strategy is not merely to provide technical prescriptions for policy reform, but to engage in a collaborative effort with host governments and donor agencies to identify and analyze the issues at hand, arrive at policy solutions, and implement reforms.

ICePP specializes in four broad policy areas:

- Fiscal policy (including tax reforms, public expenditure reviews, tax administration reform)

- Fiscal decentralization (including decentralization reforms, design of intergovernmental transfer systems, urban government finance)

- Budgeting and fiscal management (including local government budgeting, performancebased budgeting, capital budgeting, multi-year budgeting)

- Economic analysis and revenue forecasting (including micro-simulation, time series forecasting)

For more information about our technical assistance activities and training programs, please visit our website at http://icepp.gsu.edu or contact us by email at paulbenson@gsu.edu. 


\title{
Trust in Government Institutions and Tax Morale
}

\author{
Antonios M. Koumpias ${ }^{1, *}$, Gabriel Leonardo ${ }^{2}$, and Jorge Martinez-Vazquez ${ }^{2}$
}

February 2020

\begin{abstract}
What actions do governments around the world take that may affect individuals' trust in the government that positively influence tax morale (or a positive attitude toward tax compliance)? This paper researches which are the most salient government institutions that breed individual trust and the extent to which this trust ends up increasing citizens' tax morale. We use cross-country survey information from the World Values Survey and the Freedom House spanning 92 countries and six survey waves during the period 1981-2014. Conditional on the level of political rights and civil liberties, we confirm prior evidence that trust in government organizations positively influences tax morale. More importantly, our findings show that it is trust in output government organizations that implement and deliver public goods and services to the citizenry that has a significantly larger impact on tax morale as compared to citizens' trust in input-side organizations, such as the legislative and the executive branches of the government that design policy. We also exploit periods of democratic transitions, when large variations in trust may be present, to assess the role of trust in government organizations for tax morale using a treatment effects model. Our results reveal a robust, positive impact of negative democratic transitions on tax morale.
\end{abstract}

Keywords: Tax morale, tax compliance, trust in government, government institutions, democratic transition, World Values Survey

JEL classification: $\mathrm{H} 26, \mathrm{~K} 42$

* Corresponding author|koumpias@umich.edu

${ }^{1}$ Koumpias: Department of Social Sciences, University of Michigan-Dearborn

${ }^{2}$ Leonardo and Martinez-Vazquez: International Center for Public Policy, Department of Economics, Andrew Young School of Policy Studies, Georgia State University

Acknowledgements: We are grateful to Benno Torgler, Alberto Chong and conference participants at the 2017 National Tax Association Meetings for very helpful comments. All remaining errors remain our own. 


\section{Introduction}

Does trust in government organizations influence individuals' tax morale? ${ }^{1}$ If so, is it trust in political institutions (input side) or administrative government organizations (output side) that matters the most? And does variation in political rights and civil liberties due to democratic transitions affect these relationships? These are important questions as it is not entirely clear what is that government does to successfully elicit taxpayers' trust. In this paper we draw from the recent literature on social capital and institutional trust which highlights that treating trust in different government institutions similarly, as in a general "trust in government," glosses over the different ways by which citizens come to trust distinct government institutions (Rothstein and Stolle, 2008). ${ }^{2}$ We distinguish between organizations on the output side of government such as those charged with delivering civil services or policing as well as the courts and the input side of government, which includes the political organizations of government such as the legislative and the executive branches of the government that design policy.

Allingham and Sandmo (1972) (“AS") provided the theoretical underpinnings for an answer to why individuals pay their taxes based on deterrence motives (Becker, 1968). However, lab and field experiments indicate that the average level of taxpayer compliance would appear to exceed what the AS model would predict based on the actual probabilities of audit and effective penalties (Alm et al., 2010). In addition, the model's exclusive reliance on pecuniary incentives overlooks voluntary tax compliance (Feld and Frey, 2002, 2007). ${ }^{3}$

\footnotetext{
${ }^{1}$ Tax morale has been defined as voluntary compliance with tax laws, an "umbrella term capturing nonpecuniary motivations for tax compliance" such as intrinsic motivations, social or cultural norms, and departures from the behaviors predicted by the expected utility framework (Torgler, 2006; Luttmer and Singhal, 2014).

${ }^{2}$ As is customary in the tax morale literature, we measure "trust in government" using World Values Survey responses to "how much confidence" in different government branches do individual have (Daude et al., 2013).

${ }^{3}$ Voluntary compliance may be also affected by the authorities' behavior. For example, taxpayers may read authorities' increased reliance on penalties and audits as a sign that they are not trusted, and thus choose to reciprocate authorities' mistrust by evading their taxes instead of increasing their compliance (Bowles 2008).
} 
The limitations of the AS model have prompted the search for extensions that may better capture the complexity of tax compliant behavior (Alm, 1999; Alm and Torgler, 2011; Slemrod, 2007). From a theoretical angle, some research has focused on the role of norms, social customs and group conformity to account for the potential moral costs incurred by taxpayers arising from any deviation from the underlying norm (Myles and Naylor, 1996; Schnellenbach, 2006). In the same spirit, Traxler (2010) incorporates tax morale into the AS model as a social norm towards tax compliance. This gives rise to a societal interdependence as the optimal taxpayer behavior is conditional on another taxpayers' compliance. Taxpayers may comply with their taxes because they feel tax compliance is a duty, which in turn increases the moral costs of engaging in tax cheating (Cyan et al., 2016; Scholz and Pinney, 1995). In turn, the duty to comply with one's tax payments may increase when taxes decrease (Scholz and Lubell, 1998a), or when taxpayers trust government and other taxpayers to hold onto their side of the tax contract (Scholz and Lubell, 1998b). This fits with the more general perspective of the role of norms in society as guiding individual behavior and reducing uncertainty in exchange (North, 1994). Thus, norms would seem to act as devices helping individuals to make their own tax compliance decisions (Torgler, 2003b). As a consequence, instead of a single model of taxpayer behavior, we can expect a diversity of behaviors (Torgler, 2003b; Alm, 1999). With regards to the sensitivity to social norms, some individuals may be affected by what others around them think (or do) regarding compliance with taxes (Frey and Torgler, 2007), and comply or evade on the basis of what others say or do (Litina and Palivos, 2016). ${ }^{4}$ In this regard, using a randomized survey experiment, Doerrenberg and Peichl (2018) find that a statement about tax evasion rates in society can actually backfire by effectively

\footnotetext{
${ }^{4}$ Because tax compliance can be interpreted to be quasi-voluntary (Levi, 1998; Braithwaite, 2003), individuals may also learn social norms on compliance (Ostrom, 1998).
} 
decreasing tax morale. Although there is still limited evidence of a causal link between tax compliance attitudes and actual tax compliant behavior (Halla, 2011), an increasing list of empirical findings show plausibly that tax morale may influence taxpayer behavior (Torgler, 2002b; Alm and Torgler, 2006, Torgler and Schneider, 2007; Cummings et al., 2009; Koumpias and Martinez-Vazquez, 2019). ${ }^{5}$

In this paper we seek two main goals: to bring more clarity on what form of trust in government positively affects tax morale, and how the interaction of trust in government and the manner in which government power is actually exercised may jointly influence tax morale (Alm and Torgler, 2006, Chan et al., 2017; Cyan et al., 2016; Martinez-Vazquez and Torgler, 2009; Slemrod, 2003; Torgler 2003b, 2005a, 2005b). Empirically we employ individual survey information from the World Values Survey (WVS) covering 92 countries in six waves that intermittently span a total of 30 years from 1981 to 2014 with a lapse of coverage from 1985 till 1988. We test four hypotheses: (H1) whether trust in government positively affects tax morale: (H2) which types of government organizations specifically are most salient in increasing tax morale; (H3) what is the direct impact of positive and negative democratic transitions (respectively, enhancing and undermined political rights and civil liberties) on tax morale; and (iv) how does democratic transition condition the impact of trust on different types government organizations.

The main contribution of this work is the extension of our understanding on how trust in different types of government organizations influences tax morale and how those effects may be conditioned in situations of democratic transition.

\footnotetext{
${ }^{5}$ Recent clinical evidence based on a physiological marker also points towards a potential link between social norms and tax compliance. Dulleck et al. (2016) proxy psychic costs through a measure of heart rate variability and find a positive association between psychic stress and tax compliance.
} 
Empirically, we find that trust in government organizations increase the probability of reporting high tax morale across the board with effect sizes ranging from 2.31 per cent to 3.16 per cent across different government organizations. Our second main finding is that tax morale is most affected by the level of trust in government organizations that implement and deliver public goods and services to the citizenry; i.e., trust in output government organizations has a stronger and more robust positive association with tax morale than trust in input government organizations. Third, we find that negative democratic transitions have a more positive impact on tax morale than positive transitions. In addition, the interactive effects of trust in different government organizations and democratic transitions unveil substantial heterogeneity in the tax morale response.

The plan for the rest of the paper is as follows. The second section reviews the literature exploring the impact of trust in government on tax morale. In the third section we develop a conceptual framework of how governments may elicit trust and ultimately affect individuals' willingness to voluntarily comply with the tax laws. The fourth section describes the data and empirical approach we employ. The fifth section presents and interprets our results, and the sixth section concludes.

\section{Literature Review}

Tax morale is shortly defined as the intrinsic motivation to pay taxes (Torgler, 2006). A more inclusive definition is offered by Luttmer and Singhal (2014) who highlight five mechanisms through which tax morale could influence individual tax compliance: intrinsic motivations, reciprocity, peer effects and social influences, culture, and information. ${ }^{6}$ A consistent finding in

\footnotetext{
${ }^{6}$ This may not be an exhaustive list, of course. For example, Filippin et al. (2013) using survey data from Italy, also identify stricter formal law enforcement as an institutional factor that can enhance tax morale.
} 
the previous literature is that trust in government positively affects individuals' willingness to comply with the tax laws. In particular, higher trust in the country's legal system, the government, and the parliament, have all been found to increase individual tax morale (Torgler, 2003a, 2003b, 2005; Cummings et al., 2009; Cyan et al., 2016, 2017; Alm and Torgler, 2006; Torgler and Schneider, 2007; Martinez-Vazquez and Torgler, 2009; Lago-Peñas and Lago-Peñas, 2010) Other factors such as upholding religious beliefs, support for democracy, and pride in one's national origin also have been found to influence tax morale in a positive way (Torgler, 2005b, 2006). In this regard, Orviska and Hudson (2003), using information from the British Social Attitudes Survey, find that law abidance and civic duty work to actually lower tax evasion (as one would expect from higher tax morale).

Although these reported empirical findings strongly indicate that trusting government is associated with higher willingness to comply with the tax laws, it is much less well-known what is that government does to trigger taxpayers' trust. Two main explanations on how governments affect trust may be found in the literature. First, it has been theorized that governments may elicit trust when they deliver what taxpayers demand. For instance, widespread support for the programs provided by government legitimates government actions and may impose a social norm towards paying taxes (Alm and Martinez-Vazquez, 2007). Voters supporting the winning party would expect it to implement the policies they favor (Rothstein and Stolle, 2008), which means that government policies earn trust from those who support them and disappoint and lose trust from those voters who oppose them (Citrin, 1974). At the same time, this suggest that individuals would distrust those officials who implement policies they do not favor and, consequently, would not be willing to comply with their tax obligations. Thus, overall, the link between meeting individual policy preferences and tax compliance is a complex one. 
A second explanation that has been suggested is that governments that are perceived as being fair may elicit individual trust (Alm and Torgler, 2006). In this respect, experimental evidence suggests that individuals are more compliant when they have a voice in how their taxes are spent and vice-versa (Alm et al., 1993; Wahl et al., 2010; Casal et al., 2016; Drogalas et al., 2018) and have a say in how tax enforcement should be done (Alm, 1999). Consistent with the idea that democracy gives individuals an opportunity to get the public goods they desire (Rohrschneider, 2005), taxpayers tend to be more compliant when they are given an outlet to express their opinion about what policies should be adopted. For example, survey evidence from Switzerland showed a positive relationship between direct democracy and taxpayer satisfaction (Frey and Stutzer, 2005). Those findings complement earlier results that in cantons where direct democratic rights were more developed, the average size of tax evasion was smaller (Pommerehne and Weck-Hannemann, 1996, Torgler 2005a). ${ }^{7}$

\section{Conceptual Framework}

First, in order to understand which government actions elicit trust, and where in government those actions are carried out, we separate government organizations into input and output organizations (Rothstein, 2005). The input side of government is its political side; it converts individual preferences into policies that will help produce, among other things, the goods and services that individuals want government to provide. The output side fulfills an administrative role of delivering the goods and services decided upon on the input side. Table B.1 in the Appendix lists input, and output organizations of the government, which respectively include the government or Parliament, and civil services, the courts, or the police.

\footnotetext{
${ }^{7}$ More generally, the presence of referendum institutions could be another potential mechanism through which trust is linked to tax morale (Hug and Spörri, 2011).
} 
Second, to assess how the interaction between trust and power affect tax we use democratic transitions to proxy for substantial variation of trust and power of different government organizations. One might expect differential effects of increased trust in input and output organizations on tax morale in response to positive and negative democratic transitions. These transitions are the result of significant shifts, either an attack on or a victory, in political rights and civil liberties that are sufficiently large to cause a change of status in the country's designation as Free, Partially-free or Not Free in the Freedom House survey. Arguably, a positive democratic transition which involves changes in input organizations of the government that may empower individual citizens is more likely to spur higher tax morale between individuals with trust in input as opposed to output organizations. Lab experiments suggest that allowing for voice on tax contributions and distributions leads to higher tax morale (Casal et al., 2016). On the contrary, a negative democratic transition that may be linked to a shift closer to ruling with an "iron fist" may increase perceptions of the power of government organizations and, particularly, of output side ones, which include tax authorities.

\subsection{Input and Output Government Organizations}

The input side of government is constituted by the political organizations of government the legislative and executive branches. Their members are elected to advance the policies favored by the electorate who supported them. Therefore, the policies they advance may certainly favor certain groups over others (Rothstein 2005).

The partisan character of input organizations makes it more challenging for them to elicit widespread trust among taxpayers. For example, in Sweden people place higher trust in government organizations whose members are not elected (e.g. public schools, health care system, 
and the police) than in the representative organizations of democracy such as political parties or parliaments (Rothstein, 2005).

Another obstacle with the input side of government as generator of trust stems from the fact that voting does not necessarily ensure fair results. Madison (1788) observed this shortcoming of democracy and underlined that individual freedoms are threatened not only by government actions, but also by the decisions of majorities that might undermine minorities' freedoms. Levi (1998) pointed out that the introduction of safeguards to protect minorities may reduce the danger of a "dictatorship of the majority" at the expense of the majority's resentment.

Consequently, for all the reasons above, it seems unlikely that input government organizations would elicit from their actions a very high level of taxpayers' trust and tax morale.

Output organizations are in charge of delivering public goods and services to individuals which are previously decided upon by the input institutions of government. Therefore, output organizations are not concerned with what should be delivered, but instead with how those goods and services are actually delivered. Building a relationship of trust between taxpayers and the tax administration (an organization of the output side of government) has been seen as critical to increase voluntary tax compliance (Alm and Martinez-Vazquez, 2007; Kirchler et al., 2008). Taxpayers are no longer seen as subordinates of the state, but instead more as partners of the tax administration, that are more likely to willfully comply (Rothstein, 2005). When treating taxpayers more as partners, tax authorities deliver good governance that is supportive of democratic principles (Braithwaite, 2003).

\subsection{Trust in and Power of Government Organizations and Tax Morale}

The recent literature on trust in tax authorities and tax compliance highlights two elements. One is the role that direct interaction between government officials and taxpayers may have in 
eliciting voluntary tax compliance, and the second concerns how taxpayers are treated by authorities. Direct contact between individuals is at the cornerstone of building a trust relationship because it provides the parties with superior clues regarding the other side's trustworthiness (Ostrom, 1998). Taxpayers are likely to trust (or distrust) tax authorities depending on their experiences dealing with them in direct interactions (Gangl et al., 2013). However, tax administrations are not the only government institution taxpayers deal with. Since other institutions of the output side of government also deliver governance consistent with democratic principles, they may jointly influence individual willingness to comply with tax laws.

There is a broad consensus on how issues of fairness and legitimacy affect trust in authorities in a variety of arenas impacting: (i) voluntary compliance with their norms and requests (Levi, 1998; Levi and Stoker, 2000; Rothstein, 2005, 2009; Rothstein and Teorell 2008); (ii) tax compliance (Frey and Feld, 2002; Murphy, 2004; Alm and Martinez-Vazquez, 2007; Feld and Frey, 2007; (iii) law enforcement (Sunshine and Tyler, 2003); and (iv) cooperation with authorities (De Cremer and Tyler, 2007).

Economists have started to explore whether procedural justice is a source of satisfaction for individuals in the same way that consumption of goods and services increases individual utility (Frey et al., 2004; Frey and Stutzer, 2005). Obtaining satisfaction from receiving fair treatment may be the reason behind the experimental finding that allowing taxpayers to vote leads to increased tax compliance (Alm et al., 1993, 1999; Feld and Tyran, 2002; Wahl et al., 2010).

In understanding where trust is created, we must note that individuals most likely do not treat government institutions as a single monolithic entity. Rothstein and Stolle's (2008) factor analysis evaluating whether individuals trust all government institutions the same way revealed 
that two dimensions of institutional trust emerge. Institutions belonging to the input side of government such as parliaments, political parties, and government fall within the same dimension, whereas institutions from the output side such as the police, the army, and legal institutions, load on a different dimension. An additional analysis using Sweden's SOM survey produced similar results.

The arguments above strongly suggest that the kind of trust in government that would affect tax morale is likely to come, at least more strongly, from the treatment received by individuals in the output side of government. Other than affecting individual well-being, interaction with output organizations also informs citizens on how government regards them (North, 1994).

We therefore pose the following hypotheses that will be empirically tested in the following section:

H1: Individuals who trust government would show higher tax morale than those who do not trust it

$\mathrm{H} 2$ : Individuals who trust the output organizations of government would show even stronger tax morale

H3: A positive (negative) democratic transition would be associated with high (low) tax morale.

H4: Individuals with trust in input organizations of government in countries experiencing a positive (negative) democratic transition would exhibit higher (lower) tax morale than those individuals who trust output organizations under the same democratic transitions conditions.

\section{Data and Empirical Approach}

\subsection{Data Sources}


We employ survey information from all six waves of the World Values Survey (WVS), which collects individuals' opinions on a large array of topics, spanning two periods, 1981-85 and 1988-2014, and covering 92 countries, ranging from full-fledged democracies to one-party governments (Inglehart et al., 2014). ${ }^{8}$ Coverage is uneven; only five countries appear in all six WVS survey waves, while 30 countries appear in only one. As a result, our dataset should be understood as pooled cross-sectional observations at the individual level from an unbalanced panel of countries.

Differences in political systems may influence how individuals come to trust authorities. Individuals appreciate the trust government places in them and in turn may become more willing to comply with taxes (Alm et al., 1993; Wahl et al., 2010). Thus, higher tax compliance may be associated with governance practices consistent with democratic principles (Braithwaite, 2003). For these reasons we need to control for the differences in political regimes from full-fledged democracies and other types of regimes.

To control for the different ways that governments interact with their citizens, we use the Freedom in the World survey. ${ }^{9}$ The survey assesses a country's level of political rights and civil liberties enjoyed by their inhabitants. Each dimension generates a score from 1 to 7 , with lower values meaning higher degree of political and civil rights. The survey ranks annually most countries in the world, and groups them as free countries (with scores from 1 up to 2.5), partiallyfree countries (with scores between 3 and 5.5, and between 3 and 5 beginning with the 2003 ratings onwards), and not-free countries (with scores 5.5 and above). In the empirical analysis, we use this

\footnotetext{
${ }^{8}$ The WVS team controls the accuracy of surveys by providing the main questionnaire (in English) to each country team which translates it into the local language(s). In turn, the local teams submit the local questionnaires to a different translator who translates it back to English.

${ }^{9}$ Freedom House, Country and Territory Ratings and Statuses 1973-2018:

https://freedomhouse.org/content/freedom-world-data-and-resources
} 
latter information in two different ways. First, these composite scores enter as continuous control variables in standard logit regression models. Second, they are used to generate indicators of democratic transition from free - in the parlance of the survey -, partially-free, or not free statussee Table B.2 in the Appendix. That is, the positive democratic transition indicator is equal to one when a country's status on the Freedom in the World survey improves (from Not Free to Partially-

free or Free, from Partially-free to Free) and zero, otherwise. Conversely, the negative democratic transition indicator is equal to one when a country's status deteriorates (from Free to Partially-free or Not Free, from Partially-free to Not Free), and zero, otherwise. This allows us to exploit changes in underlying political institution arrangements as identifying variation of the role of trust in different government functions on tax morale. We believe this measure of political freedom sums in the most holistic - yet arguably coarse - way how government policies affect individual attitudes towards the government as a whole, including tax morale.

\subsection{Model Selection}

This subsection describes how we construct our dependent variable, tax morale, and our key independent variables of trust in government and democratic transition, and the additional control variables already well identified in the previous literature.

The question in the WVS that we use to generate our tax morale binary outcome variable is:

"Please tell me whether you think cheating on taxes if you have a chance can always be justified, never be justified, or something in between (1-10 scale: 1: never justifiable; 10: always justifiable)."

We code tax morale into a binary variable that measures high tax morale taking the value of one when cheating on taxes is never justifiable (WVS scale 1) and zero, otherwise (WVS scale 
$2-10) .{ }^{10}$ This choice is motivated by the empirical distribution of the survey responses of the WVS' tax morale variable and confirmed via a statistical test using a stereotype logit regression model (Liu, 2014). Figure A.1 in the Appendix presents the histogram of the 10-point WVS scale of responses to the survey question. The mass of survey responses $(62.07 \%)$ is concentrated on the extreme "cheating on taxes is never justifiable" making it a natural candidate to model it separately. The remaining responses are fairly evenly distributed over the other nine possible values. Respondents seem to differentiate between "cheating on taxes is never justifiable" and all other responses. The stereotype logistic regression model allows us to formally test whether respondents differentiate between the values of the 10-point scale based on the empirical distribution of the tax morale variable. In the majority of statistical tests, survey responses 2 through 9 are statistically indistinguishable. ${ }^{11}$ These findings make a strong case for coding individual WVS tax morale survey responses into a binary variable.

Although the WVS is generally employed in the tax morale literature, it is not free of the general shortcomings associated with self-reported answers. A prominent shortcoming is that individuals' answers to the question may not correlate with actual tax behavior; some individuals may want to make up for past behavior by asserting high tax morale in survey responses. Several papers (Cummings et al., 2009; Halla, 2012; Koumpias and Martinez-Vazquez, 2019) have shown evidence of a causal link between tax morale and a some measure of tax compliance. Other issues contemplated in the literature, such as the problems derived from using a single question to

\footnotetext{
${ }^{10}$ Typically, tax morale is coded into an ordered variable in four different categories. See, for example, Torgler (2006) and Rodriguez-Justicia and Theilen (2018) but a binary approach has been preferred in other recent studies, too (Doerrenberg and Peichl, 2018).

${ }^{11}$ Each response value is represented by a scale parameter $\varphi_{1 \mathrm{i}}, \mathrm{i}=1, \ldots, 10$. The parameter representing the extreme responses "cheating on taxes is never justifiable" and "cheating on taxes is always justifiable" are denoted by $\varphi_{-} 11$ (corner constraint set equal to 1) and $\varphi_{-} 19$ (base outcome set equal to zero). We find very precise evidence that respondents strongly distinguish between value 1 (corner constraint $\left.\varphi_{-} 11\right)$ and values 2 through $9\left(\varphi_{-} 12, \ldots, \varphi_{-} 19\right)$. In addition, in the majority of tests assessing whether each one of the intermediate parameters $\varphi_{-} 12, \ldots, \varphi_{-} 19$ is equal to its following one $\left(\varphi_{-} 12=\varphi_{-} 13, \ldots, \varphi_{-} 18=\varphi_{-} 19\right)$, we fail to reject the hypothesis they are equal to each other.
} 
measure tax morale, are counter-balanced by the difficulties in assembling indexes because of the correlation among components and deciding on the relative importance (weights) of each component (Alm and Torgler, 2006).

Next, we discuss the variables used to test the proposition that government organizations on the output side may be more salient in driving tax morale. The question in the WVS that asks individuals how much they trust different government organizations reads:

"I am going to name a number of organizations. For each one, could you tell me how much confidence you have in them: is it a great deal of confidence, quite a lot of confidence, not very much confidence or none at all? (4-scale item, coded $1=$ a great deal... 4=none at all)"

We code trust in the different government organizations as indicator variables that take the value of 1 when survey respondents have either "a great deal of confidence" or "quite a lot of confidence" in the government organization at hand; zero, otherwise:

Trust in the Government. This independent variable is capturing individual trust in the national government at the time of the survey. For brevity, we will, thereafter, refer to this inputside government organization as "government." It is also the government organization with which respondents are expected to be most familiar. We expect a positive sign between trust in the government and tax morale.

Trust in the Civil Service. This variable measures individual trust in government bureaucracies, which are in charge of service delivery in health, education, social services, and so on. "Civil service" may not fully capture individual experience with the output side of government; ${ }^{12}$ measures of trust in specific organizations (e.g. school system or social welfare)

\footnotetext{
${ }^{12}$ Rothstein and Stolle (2008) contended that trust in Civil Service may be considered as trust in the political appointees populating the high ranks of state organizations, which would make it to be closer to input side institutions.
} 
would be a better alternative, but they are not available. ${ }^{13} \mathrm{We}$ expect a positive sign between trust in civil services and tax morale.

Trust in Police. The role of this government organization is to protect individuals' lives and property. Police actions fall right into the output side of government. The expected sign of the coefficient is positive.

Trust in the Courts. The relationship between the courts and the legal system, an outputside government organization, in eliciting individual tax morale has been explored in previous studies and found to be empirically supported (Torgler 2003a, 2003b, 2003c, 2004a; Torgler and Murphy, 2005). One possible issue relates to the extent which individuals interact with the legal system and courts. The same positive association is expected between trust in courts and tax morale, albeit of potentially smaller magnitude due to less exposure of individuals to the courts as opposed to civil services.

Trust in Parliament. Higher trust in legislatures has been found in the previous literature to increase tax morale (Torgler 2003a, 2004a; Torgler and Murphy, 2005; Martinez-Vazquez and Torgler, 2009). The interpretation of the variable is partially complicated by the fact that trust in parliament may gauge not only trust in the institution but also trust in the incumbents, and therefore survey responses may also express attitudes towards members of the parliament in the opposition (Citrin, 1974). Trust in the parliament is expected to be positively correlated with tax morale but a less pronounced effect is possible because respondents may also be expressing their attitudes towards members of the parliament in the opposition.

\footnotetext{
${ }^{13}$ Even if we had measures of individual trust from several output organizations, it could be difficult to ascertain their relative relevance in shaping individual Tax Morale because of different country arrangements for different functions. For example, healthcare in the U.S. is provided mainly by private providers whereas in many Western European countries, Canada, and Japan, the arrangements include government organizations in varied degrees.
} 
We further exploit events of substantial changes in the political system that may provide identifying variation in individual attitudes towards trust in government organizations. We do so by creating an indicator of positive and negative democratic transition. Based on the Freedom House information, the indicator of positive democratic transition takes the value of one when countries become either free or partially-free from partially-free or not free; zero, otherwise. In an analogous fashion, we generated an indicator of negative democratic transition when the status of a country's political system changes from free to partially-free or from partially-free to not free.

Individual support for democracy has been found in the previous literature to positively affect tax morale (Torgler, 2003c, 2004b, 2005b; Torgler and Schneider, 2007). Moreover, the availability of direct democratic practices such as referenda has been shown to increase tax morale among Swiss taxpayers (Torgler, 2005a). However, Inglehart (2003) in examining the issue of how to measure support for democracy noted that measures of overt support may be misleading because a substantial proportion of democracy supporters also support non-democratic regime types, even among those living in well-established democracies. Consequently, following Linde (2012), we use a binary measure of democratic support gauging individuals' rejection of nondemocratic regimes.

Finally, we include in our analysis a number of other predictors of tax morale identified in the previous literature, including demographics such as age and gender, as well as information on socio-economic status, such as income, marital status, educational attainment, and employment status. We expect females, married and older respondents to exhibit higher tax morale than males, singles, or younger individuals (Torgler, 2004c; Torgler, 2007a; Hug and Spörri, 2011; Cyan et al., 2016). The educational attainment variable is measured in 9 scales which we recode into 4 binary variables of increasingly higher educational attainment: no or some education up to 
elementary school, vocational school, secondary and higher education. The evidence on the relationship between educational attainment and tax morale is mixed with a number of studies reporting either a positive (Torgler, 2005a, 2005b; Konrad and Qari, 2012; Rodriguez-Justicia and Theilen, 2018) or a negative relationship (Lago-Peñas and Lago-Peñas, 2010; Doerrenberg and Peichl, 2013). The 10-scale income measure in the WVS has been documented to suffer from measurement error and coverage problems such as inconsistencies across countries (Layard et al., 2008). As a result, the same income scale corresponds to substantially different income intervals in different countries, which poses analytical challenges for cross-country analyses (Donnelly and Pop-Eleches, 2018).

Despite these limitations, some researchers have simply used the original income variable in the WVS and interpreted it as income deciles (Ingehart et al., 2008). Donnelly and Pop-Eleches (2018) apply a series of corrections to a subset of WVS country surveys to construct and make publicly available a measure of income at purchasing power parity (or exchange rate) in 2005 US dollars. ${ }^{14}$ Other solutions offered in the literature include collapsing the 10 -scale variable into quintiles (Solt, 2008); or creating three categories of income that approximates terciles (Alesina and Giuliano, 2011). We follow this latter approach and construct low, middle, and high-income indicators that correspond to scales 1-3, 4-7, and 8-10, respectively. Respondents in the lowest income tercile are more likely to report high tax morale relative to those in the middle tercile, while those in the top tercile may exhibit lower tax morale due to the heavier tax burden they bear (Torgler, 2002a).

With regards to employment status, salaried individuals who are likely to be subject to tax withholding are also expected to have higher tax morale than those self-employed. Religiosity is

\footnotetext{
${ }^{14}$ However, the dataset spans 137 out of 241 countries from the first five waves of the WVS and, thus, does not sufficiently overlap with our study sample in time and space.
} 
suggestive of individual involvement with formal religion, gauged by attendance at religious services, has been found to be an important determinant of tax morale (Torgler, 2003a, 2005a, 2006; Alm and Torgler, 2006, Torgler and Schneider, 2007; Torgler and Martinez-Vazquez, 2009). National pride has also been linked to tax morale in previous studies (Torgler, 2005b; Torgler and Schneider, 2004; Martinez-Vazquez and Torgler, 2009; Konrad and Qari, 2012). Similarly, to our construction of support for democracy, we code the qualitative responses to national pride and religiosity as indicators that take the value of one when respondent have the most positive attitudes ("Religion is very important in life", "very proud").

\subsection{Logit Regression Models}

In order to estimate the impact of trust in institutions on tax morale we specify and estimate several empirical models. First, we employ a logit regression model that allows us to test our first two hypotheses: H1: Trust in government is associated with higher tax morale; and $\mathrm{H} 2$ : Trust in output-side organizations of the government is more strongly associated with tax morale than trust in input-side organizations of the government.

The logit model we estimate is given by:

$$
\begin{aligned}
H_{T M} M_{i j t}=\beta_{0} & +\sum_{l}^{1, \ldots, 4} \beta_{l} \text { TRUSTGOV }_{i t}+\beta_{6} \text { RELIG }_{i t}+\beta_{7} \text { NPRIDE }_{i t}+\sum_{l}^{8, \ldots, 13} \beta_{l} X_{i t} \\
& +\boldsymbol{I}\left(\operatorname{COUNTRY}_{j}\right) \boldsymbol{\beta}_{\mathbf{1 4}}+\boldsymbol{I}\left(\text { WAVE }_{t}\right) \boldsymbol{\beta}_{\mathbf{1 5}}+\varepsilon_{i t}(1)
\end{aligned}
$$

where our dependent variable $H T M_{i j t}$ is High Tax Morale, measuring individual $i$ 's willingness to comply with tax laws in country $j$ at WVS wave $t$ based on whether she believes cheating on taxes is "never justifiable". We include a vector of five variables, $\Sigma_{l}^{1, \ldots, 4} \beta_{l}$ TRUSTGOV ${ }_{i t}$ which collects all four key independent variables with information about respondents' trust in different government functions in both the input and the output side.

Besides the "Trust in Government" variables of interest we control for several other 
determinants of tax morale as discussed above: age, indicators of religiosity, national pride, being female, being single, low- and high-income terciles and employment status. It should be noted though that the support for democracy survey question was not asked to more than half of the total respondents in all six waves of the WVS. Thus, to avoid discarding more than half of the observations, we only include this variable in a supplemental specification.

Finally, we include dummy variables to control for country $j$ and WVS-wave $t$ fixed effects in vectors $\boldsymbol{I}\left(\operatorname{COUNTR} Y_{j}\right)$ and $\boldsymbol{I}\left(W A V E_{t}\right)$ and cluster standard errors at the country level.

\subsection{Democratic Transition Treatment Effects Model}

Next, we present a supplemental empirical strategy to test hypotheses $\mathrm{H} 3$ and $\mathrm{H} 4$. Using a comparative case study framework, we exploit instances of democratic transition to estimate the relationship of trust in government organizations and tax morale after periods of heightened political transition processes.

$$
\begin{aligned}
\text {HTM }_{i j t}=\delta_{0}+ & \delta_{1} \text { PositiveDemTrans }_{i j t}+\sum_{l}^{2, \ldots, 6} \delta_{l} \text { TRUSTGOV }_{i j t}+\sum_{k}^{1, \ldots, 5} \rho_{k} \text { TRUSTGOV }_{i j t} \\
& * \text { PositiveDemTrans }_{i j t}+\gamma_{1} \text { NegativeDemTrans }_{i j t}+\sum_{k}^{6, \ldots, 10} \rho_{k} \text { TRUSTGOV }_{i j t} \\
& * \text { NegativeDemTrans }_{i j t}+\sum_{l}^{7, \ldots, 15} \delta_{l} X_{i t}+\boldsymbol{\delta}_{\mathbf{1 6}} \mathbf{I}\left(\text { COUNTRY }_{j}\right)+\boldsymbol{\delta}_{\mathbf{1 7}} \boldsymbol{I}\left(\text { WAVE }_{t}\right) \\
& +\xi_{i t}(2)
\end{aligned}
$$

where our dependent variable $H T M_{i j t}$ is High Tax Morale, measuring individual $i$ 's willingness to comply with tax laws in country $j$ at WVS wave $t$ when perceiving cheating on taxes as "never justifiable".

One should be careful in their interpretation given that they involve interaction terms of indicator variables. Specifically, $\delta_{1}$ and $\gamma_{1}$ denote the overall effect of a positive and a negative 
democratic transition on tax morale in the absence of trust in government, respectively. Parameters $\delta_{l}, l=2, \ldots, 6$ capture the correlation between trust in a government function of the five we consider and tax morale in the absence of democratic transition. The incremental effects of a positive and a negative democratic transition and trust in government relative to trust in government in the absence of any transition are equal to $\delta_{1}+\rho_{k^{\prime}} l=2, \ldots, 6, k=1, \ldots, 5$ and $\gamma_{1}+$ $\rho_{k^{\prime}} l=2, \ldots, 6, k=6, \ldots, 10$, respectively. Similarly, the incremental effects relative to a positive or a negative democratic transition with lack of trust in any government function are equal to $\delta_{l}+$ $\rho_{k^{\prime}} l=2, \ldots, 6, k=1, \ldots, 5$ and $\delta_{l}+\rho_{k^{\prime}} l=2, \ldots, 6, k=6, \ldots, 10$, respectively. Finally, the effects of a positive and negative transition given trust in government to lack of trust in a period of no democratic transition is given by $\delta_{1}+\delta_{l}+\rho_{k^{\prime}}, l=2, \ldots, 6, k=1, \ldots, 5$ and $\gamma_{1}+\delta_{l}+\rho_{k^{\prime}} l=$ $2, \ldots, 6, k=6, \ldots, 10$, respectively

As in the logit regression models, we control for the same determinants of tax morale collected in vector $X_{i t}$ in equation (1), as well as support for democracy, religiosity, and national pride.

\section{Results}

First, we present the results of the logit regression model (equation 1) in Table 1. Those with national pride have a much higher probability of reporting high tax morale, holding all other variables at their means. The impact of religiosity is also positive, but smaller. This latter echoes Dalton's (1996) observation that religious affiliation is losing its relevance in providing individuals with guidance about civil-political issues. Females are more likely to report high tax morale compared to males and older individuals are more likely to report tax morale than younger ones. In the same fashion, retirees are also positively associated with higher tax morale. But, as the coefficients for the different measures of employment status indicate, the determining 
factor is not being employed or retired but rather the nature of employment; self-employed respondents show less tax morale relative to salaried workers. The same holds for part-time workers who share some common employment characteristics with the self-employed. In addition, those with no or very low educational attainment (up to elementary school) are significantly less likely to report high tax morale in all specifications but those in columns (4) and (6), which supports the similar findings by McGee and Ross (2012). The least wealthy respondents (those in the lowest income tercile) have higher tax morale relative to respondents in the second tercile.

Table 1: Logit Regression Model Coefficient Estimates

\begin{tabular}{|c|c|c|c|c|c|c|}
\hline VARIABLES & $\begin{array}{c}(1) \\
\text { Government }\end{array}$ & $\begin{array}{c}\text { (2) } \\
\text { Civil Services }\end{array}$ & $\begin{array}{c}\text { (3) } \\
\text { Parliament }\end{array}$ & $\begin{array}{c}\text { (4) } \\
\text { Courts }\end{array}$ & $\begin{array}{c}(5) \\
\text { Police }\end{array}$ & $\begin{array}{l}\text { (6) } \\
\text { All }\end{array}$ \\
\hline Trust in Government & $\begin{array}{l}0.123 * * * \\
(0.0288)\end{array}$ & & & & & $\begin{array}{c}0.0525 \\
(0.0269)\end{array}$ \\
\hline $\begin{array}{l}\text { Trust in Civil } \\
\text { Services }\end{array}$ & & $0.116 * * *$ & & & & $0.0712 * *$ \\
\hline & & $(0.0231)$ & & & & $(0.0261)$ \\
\hline Trust in Parliament & & & $\begin{array}{c}0.100 * * * \\
(0.0267)\end{array}$ & & & $\begin{array}{l}-0.0116 \\
(0.0248)\end{array}$ \\
\hline Trust in Courts & & & & $\begin{array}{c}0.117 * * * \\
(0.0234)\end{array}$ & & $\begin{array}{c}0.0361 \\
(0.0226)\end{array}$ \\
\hline Trust in Police & & & & & $\begin{array}{c}0.138 * * * \\
(0.0331)\end{array}$ & $\begin{array}{c}0.0613 \\
(0.0370)\end{array}$ \\
\hline Political Rights & $\begin{array}{l}0.0470 \\
(0.110)\end{array}$ & $\begin{array}{l}0.00797 \\
(0.0905)\end{array}$ & $\begin{array}{l}0.00523 \\
(0.0915)\end{array}$ & $\begin{array}{c}-0.0916 \\
(0.105)\end{array}$ & $\begin{array}{c}0.0112 \\
(0.0904)\end{array}$ & $\begin{array}{l}-0.0616 \\
(0.132)\end{array}$ \\
\hline Civil Liberties & $\begin{array}{l}0.0603 \\
(0.152)\end{array}$ & $\begin{array}{l}0.0748 \\
(0.121)\end{array}$ & $\begin{array}{l}0.0818 \\
(0.122)\end{array}$ & $\begin{array}{c}0.240 \\
(0.146)\end{array}$ & $\begin{array}{l}0.0775 \\
(0.122)\end{array}$ & $\begin{array}{c}0.256 \\
(0.188)\end{array}$ \\
\hline National Pride & $\begin{array}{c}0.368 * * * \\
(0.0433)\end{array}$ & $\begin{array}{c}0.381 * * * \\
(0.0430)\end{array}$ & $\begin{array}{c}0.378 * * * \\
(0.0417)\end{array}$ & $\begin{array}{c}0.372 * * * \\
(0.0446)\end{array}$ & $\begin{array}{c}0.373 * * * \\
(0.0421)\end{array}$ & $\begin{array}{c}0.352 * * * \\
(0.0500)\end{array}$ \\
\hline Religiosity & $\begin{array}{l}0.231 * * * \\
(0.0302)\end{array}$ & $\begin{array}{l}0.237 * * * \\
(0.0309)\end{array}$ & $\begin{array}{l}0.232 * * * \\
(0.0309)\end{array}$ & $\begin{array}{c}0.241 * * * \\
(0.0325)\end{array}$ & $\begin{array}{c}0.232 * * * \\
(0.0302)\end{array}$ & $\begin{array}{c}0.238 * * * \\
(0.0331)\end{array}$ \\
\hline Age & $\begin{array}{l}0.0121 * * * \\
(0.000864)\end{array}$ & $\begin{array}{l}0.0126 * * * \\
(0.000893)\end{array}$ & $\begin{array}{l}0.0127 * * * \\
(0.000907)\end{array}$ & $\begin{array}{r}0.0122 * * * \\
(0.00101)\end{array}$ & $\begin{array}{l}0.0125 * * * \\
(0.000898)\end{array}$ & $\begin{array}{l}0.0116 * * * \\
(0.000977)\end{array}$ \\
\hline Female & $\begin{array}{l}0.149 * * * \\
(0.0232)\end{array}$ & $\begin{array}{l}0.147 * * * \\
(0.0214)\end{array}$ & $\begin{array}{l}0.151 * * * \\
(0.0213)\end{array}$ & $\begin{array}{c}0.148 * * * \\
(0.0228)\end{array}$ & $\begin{array}{c}0.152 * * * \\
(0.0212)\end{array}$ & $\begin{array}{c}0.141 * * * \\
(0.0262)\end{array}$ \\
\hline Elementary Ed & $\begin{array}{l}-0.0770^{*} \\
(0.0349)\end{array}$ & $\begin{array}{l}-0.100 * \\
(0.0406)\end{array}$ & $\begin{array}{l}-0.0873^{*} \\
(0.0406)\end{array}$ & $\begin{array}{l}-0.0528 \\
(0.0390)\end{array}$ & $\begin{array}{l}-0.0827 * \\
(0.0387)\end{array}$ & $\begin{array}{l}-0.0650 \\
(0.0355)\end{array}$ \\
\hline Vocational Ed & $\begin{array}{l}-0.0402 \\
(0.0260)\end{array}$ & $\begin{array}{l}-0.0502 \\
(0.0302)\end{array}$ & $\begin{array}{l}-0.0436 \\
(0.0296)\end{array}$ & $\begin{array}{l}-0.0437 \\
(0.0330)\end{array}$ & $\begin{array}{l}-0.0477 \\
(0.0285)\end{array}$ & $\begin{array}{l}-0.0402 \\
(0.0301)\end{array}$ \\
\hline Higher Ed & $\begin{array}{c}0.0363 \\
(0.0369)\end{array}$ & $\begin{array}{c}0.0327 \\
(0.0361)\end{array}$ & $\begin{array}{c}0.0352 \\
(0.0361)\end{array}$ & $\begin{array}{c}0.0401 \\
(0.0405)\end{array}$ & $\begin{array}{c}0.0303 \\
(0.0355)\end{array}$ & $\begin{array}{c}0.0525 \\
(0.0431)\end{array}$ \\
\hline Part-time & $\begin{array}{l}-0.0595^{*} \\
(0.0288)\end{array}$ & $\begin{array}{l}-0.0680^{*} \\
(0.0290)\end{array}$ & $\begin{array}{l}-0.0660^{*} \\
(0.0277)\end{array}$ & $\begin{array}{l}-0.0591 * \\
(0.0276)\end{array}$ & $\begin{array}{l}-0.0681^{*} \\
(0.0271)\end{array}$ & $\begin{array}{l}-0.0470 \\
(0.0308)\end{array}$ \\
\hline Self-employed & $\begin{array}{l}-0.0623^{*} \\
(0.0276)\end{array}$ & $\begin{array}{l}-0.0686^{*} \\
(0.0282)\end{array}$ & $\begin{array}{c}-0.0722 * * \\
(0.0270)\end{array}$ & $\begin{array}{c}-0.0757 * * \\
(0.0285)\end{array}$ & $\begin{array}{c}-0.0738^{* *} \\
(0.0263)\end{array}$ & $\begin{array}{l}-0.0602 * \\
(0.0289)\end{array}$ \\
\hline Retired & $\begin{array}{c}0.117 * * * \\
(0.0296)\end{array}$ & $\begin{array}{l}0.108 * * * \\
(0.0274)\end{array}$ & $\begin{array}{c}0.103 * * * \\
(0.0280)\end{array}$ & $\begin{array}{c}0.124 * * * \\
(0.0301)\end{array}$ & $\begin{array}{c}0.100 * * * \\
(0.0275)\end{array}$ & $\begin{array}{c}0.150 * * * \\
(0.0314)\end{array}$ \\
\hline Homemaker & 0.000788 & -0.0185 & -0.00818 & -0.00740 & -0.0136 & 0.0118 \\
\hline
\end{tabular}




\begin{tabular}{|c|c|c|c|c|c|c|}
\hline & $(0.0285)$ & $(0.0304)$ & $(0.0305)$ & $(0.0333)$ & $(0.0298)$ & $(0.0317)$ \\
\hline \multirow[t]{2}{*}{ Student } & 0.0257 & 0.0214 & 0.0239 & 0.0158 & 0.0177 & 0.0355 \\
\hline & $(0.0281)$ & $(0.0257)$ & $(0.0250)$ & $(0.0278)$ & $(0.0251)$ & $(0.0301)$ \\
\hline \multirow[t]{2}{*}{ Unemployed } & -0.0174 & -0.0328 & -0.0301 & -0.0468 & -0.0331 & -0.0217 \\
\hline & $(0.0385)$ & $(0.0382)$ & $(0.0398)$ & $(0.0475)$ & $(0.0385)$ & $(0.0493)$ \\
\hline \multirow[t]{2}{*}{ Part-time } & -0.0344 & -0.0564 & -0.0533 & -0.0732 & -0.0515 & -0.0360 \\
\hline & $(0.0870)$ & $(0.0802)$ & $(0.0794)$ & $(0.0874)$ & $(0.0865)$ & $(0.0942)$ \\
\hline \multirow[t]{2}{*}{ Single } & $-0.0772 * * *$ & $-0.0826 * * *$ & $-0.0751 * * *$ & $-0.0757 * * *$ & $-0.0726 * * *$ & $-0.0799 * * *$ \\
\hline & $(0.0178)$ & $(0.0170)$ & $(0.0170)$ & $(0.0173)$ & $(0.0164)$ & $(0.0178)$ \\
\hline \multirow[t]{2}{*}{ Low Income } & $0.104 * * *$ & $0.114 * * *$ & $0.108 * * *$ & $0.130 * * *$ & $0.113 * * *$ & $0.127 * * *$ \\
\hline & $(0.0297)$ & $(0.0276)$ & $(0.0274)$ & $(0.0303)$ & $(0.0279)$ & $(0.0341)$ \\
\hline \multirow[t]{2}{*}{ High Income } & -0.0726 & -0.0723 & -0.0704 & -0.0642 & -0.0673 & -0.0688 \\
\hline & $(0.0446)$ & $(0.0457)$ & $(0.0460)$ & $(0.0522)$ & $(0.0456)$ & $(0.0531)$ \\
\hline \multirow[t]{2}{*}{ Constant } & -0.335 & $-0.309 *$ & -0.281 & -0.229 & $-0.335^{*}$ & -0.338 \\
\hline & $(0.282)$ & $(0.145)$ & $(0.147)$ & $(0.160)$ & $(0.153)$ & $(0.291)$ \\
\hline Observations & 232,012 & 242,049 & 242,112 & 204,016 & 248,970 & 176,915 \\
\hline
\end{tabular}

Possible explanations include the fact that low-income individuals often pay very few taxes yet understand the importance of taxation to fund public services or social assistance they may rely on; alternatively, low-income individuals are averse to risk relative to medium- or high-income respondents. We cannot distinguish any statistically significant differences in tax morale between medium- and high-income respondents, confirming prior findings in the literature (Torgler, 2007). ${ }^{15}$

Logit coefficients report the change in the z-score of the dependent variable of a one-unit change in the independent variable, holding other explanatory variables at pre-determined values. To make those estimates easier to interpret, Table 2 reports the marginal effects measuring the change in the probability of reporting tax morale of a unit change in trust in the different government organizations, holding all other explanatory variables constant at their means. The estimated coefficients should be interpreted as the partial derivative of the independent variables of interest; namely, the independent variables measuring respondents' trust in different government organization.

\footnotetext{
${ }^{15}$ Including support for democracy as a regressor, we recover a large, positive and statistically significant association between individual support for democracy and tax morale.
} 
Table 2: Conditional Marginal Effects of Logit Regression Model

\begin{tabular}{|c|c|c|c|c|c|c|}
\hline VARIABLES & $\begin{array}{c}\text { (1) } \\
\text { Government }\end{array}$ & $\begin{array}{c}(2) \\
\text { Civil Services }\end{array}$ & $\begin{array}{c}\text { (3) } \\
\text { Parliament }\end{array}$ & (4) & $\begin{array}{c}(5) \\
\text { Police }\end{array}$ & (6) \\
\hline \multirow{2}{*}{$\begin{array}{l}\text { Trust in } \\
\text { Government }\end{array}$} & $0.0283 * * *$ & & & & & 0.0125 \\
\hline & $(0.00662)$ & & & & & $(0.00641)$ \\
\hline \multirow{2}{*}{$\begin{array}{l}\text { Trust in Civil } \\
\text { Services }\end{array}$} & & $0.0267 * * *$ & & & & $0.0169 * *$ \\
\hline & & $(0.00533)$ & & & & $(0.00621)$ \\
\hline \multirow[t]{2}{*}{ Trust in Parliament } & & & $0.0231 * * *$ & & & -0.00276 \\
\hline & & & $(0.00614)$ & & & $(0.00589)$ \\
\hline \multirow[t]{2}{*}{ Trust in Courts } & & & & $0.0278^{* * *}$ & & 0.00858 \\
\hline & & & & $(0.00553)$ & & $(0.00537)$ \\
\hline Trust in Police & & & & & $0.0316^{* * *}$ & 0.0146 \\
\hline & & & & & $(0.00760)$ & $(0.00879)$ \\
\hline Observations & 232,012 & 242,049 & 242,112 & 204,016 & 248,970 & 176,915 \\
\hline
\end{tabular}

The first five columns present coefficient estimates for trust in each of the four different government organizations we consider plus general trust in government. They are all positive and statistically significant. Thus, in the interpretation of our results we focus on the magnitude of the estimated coefficients to investigate any differential impact among them. For our first independent variable of interest, a one unit increase in Trust in Government (the indicator variable's value turning from zero to one) increases the probability of reporting high tax morale by about 2.83 per cent. Columns (2) and (3) report lower coefficients for the impact Trust in Civil Services and the Parliament, at 2.67 and 2.31 per cent, respectively. Possible reasons for those results in the first case may be the lack of specificity for the type of Civil Service case (it may have different meanings for different people). In the case of the Parliament, as discussed above, there are reasons to expect that Trust in this institution may not be as strongly related to tax morale because individuals may associate parliament with incumbent members from the opposition. However, we 
find strong associations between trust in courts and police at 2.78 and 3.16 per cent, respectively. ${ }^{16}$ In column (6), we report the marginal effects of trust in every government organization we consider based on a joint specification. This allows us to discern the relative importance that trust in different government organizations has on reporting high tax morale. Only trust in civil services increase the probability of reporting high tax morale by 1.69 per cent. The estimated coefficients of trust in all other government organizations are not statistically different from zero at the 5 per cent level of statistical significance. Summarizing, we find that, indeed, respondents who generally have higher trust in government organizations are linked to higher tax morale and that trust in output-side government organizations, indeed, is a stronger predictor of tax morale than trust in input-side organizations.

Table 3 shows the conditional marginal effects of the indicators of positive and negative democratic transition, trust in government organizations, as well as their interaction terms. The coefficient estimates of the full regression specified in equation (2) are omitted from the presentation to focus our attention to the marginal effects of the key independent variables.

Table 3: Conditional Marginal Effects of Democratic Transition Treatment-Effects Model

\begin{tabular}{|c|c|c|c|c|c|c|}
\hline VARIABLES & $\begin{array}{c}1) \\
\text { Governmen } \\
t\end{array}$ & $\begin{array}{c}\text { (2) } \\
\text { Civil } \\
\text { Services } \\
\end{array}$ & $\begin{array}{c}\text { (3) } \\
\text { Parliament }\end{array}$ & $\begin{array}{c}\text { (4) } \\
\text { Courts }\end{array}$ & $\begin{array}{c}\text { (5) } \\
\text { Police }\end{array}$ & $\begin{array}{l}\text { (6) } \\
\text { All }\end{array}$ \\
\hline Positive DT & $\begin{array}{c}0.0351 \\
(0.0405)\end{array}$ & $\begin{array}{c}0.0264 \\
(0.0289)\end{array}$ & $\begin{array}{c}0.0257 \\
(0.0286)\end{array}$ & $\begin{array}{c}0.00482 \\
(0.0728)\end{array}$ & $\begin{array}{c}0.0371 \\
(0.0316)\end{array}$ & $\begin{array}{c}0.102 \\
(0.0807)\end{array}$ \\
\hline Trust in Government & $\begin{array}{c}0.0307 * * * \\
(0.00610)\end{array}$ & & & & & $\begin{array}{c}0.00908 \\
(0.00625)\end{array}$ \\
\hline Trust in Government*Pos DT & $\begin{array}{l}-0.0259 \\
(0.0218)\end{array}$ & & & & & $\begin{array}{c}0.0718 \\
(0.0395)\end{array}$ \\
\hline Trust in Civil Services & & $\begin{array}{c}0.0277 * * * \\
(0.00470)\end{array}$ & & & & $\begin{array}{c}0.0143^{*} \\
(0.00580)\end{array}$ \\
\hline Trust in Civil Services*Pos DT & & $\begin{array}{l}-0.0117 \\
(0.0321)\end{array}$ & & & & $\begin{array}{c}0.0387 \\
(0.0465)\end{array}$ \\
\hline Trust in Parliament & & & $\begin{array}{c}0.0272 * * * \\
(0.00560)\end{array}$ & & & $\begin{array}{c}0.00251 \\
(0.00603)\end{array}$ \\
\hline
\end{tabular}

\footnotetext{
${ }^{16}$ Several other considerations may be behind the strong results for trust in police. For example, results from behavioral experiments indicate that direct, face-to-face communication is superior to other forms of interaction in promoting trust and cooperation (Ostrom, 2000).
} 


\begin{tabular}{|c|c|c|c|c|c|c|}
\hline Trust in Parliament*Pos DT & & & $\begin{array}{l}-0.0221 \\
(0.0299)\end{array}$ & & & $\begin{array}{l}-0.0378 \\
(0.0246)\end{array}$ \\
\hline Trust in Courts & & & & $\begin{array}{c}0.0306 * * * \\
(0.00511)\end{array}$ & & $\begin{array}{c}0.0119 * \\
(0.00564)\end{array}$ \\
\hline Trust in Courts*Pos DT & & & & $\begin{array}{c}0.00815 \\
(0.00885)\end{array}$ & & $\begin{array}{c}-0.0554 * * * \\
(0.0136)\end{array}$ \\
\hline Trust in Police & & & & & $\begin{array}{c}0.0372 * * * \\
(0.00731)\end{array}$ & $\begin{array}{c}0.0164 \\
(0.00955)\end{array}$ \\
\hline Trust in Police*Pos DT & & & & & $\begin{array}{c}-0.0525^{* *} \\
(0.0172)\end{array}$ & $\begin{array}{l}0.00286 \\
(0.0302)\end{array}$ \\
\hline Negative DT & $\begin{array}{l}0.0869 * \\
(0.0415)\end{array}$ & $\begin{array}{c}0.0821 \\
(0.0455)\end{array}$ & $\begin{array}{l}0.0934^{*} \\
(0.0387)\end{array}$ & $\begin{array}{l}0.129 * * \\
(0.0463)\end{array}$ & $\begin{array}{l}0.0993 * \\
(0.0389)\end{array}$ & $\begin{array}{l}0.143 * * \\
(0.0524)\end{array}$ \\
\hline Trust in Government*Neg DT & $\begin{array}{r}-0.00813 \\
(0.0247)\end{array}$ & & & & & $\begin{array}{l}0.0324 * \\
(0.0157)\end{array}$ \\
\hline $\begin{array}{l}\text { Trust in Civil Services*Neg } \\
\text { DT }\end{array}$ & & 0.00355 & & & & 0.0222 \\
\hline Trust in Parliament*Neg DT & & $(0.0249)$ & $\begin{array}{l}-0.0286 \\
(0.0154)\end{array}$ & & & $\begin{array}{c}(0.0201) \\
-0.0377 * * \\
(0.0118)\end{array}$ \\
\hline Trust in Courts*Neg DT & & & & $\begin{array}{l}-0.0238 \\
(0.0172)\end{array}$ & & $\begin{array}{l}-0.0266^{*} \\
(0.0133)\end{array}$ \\
\hline Trust in Police*Neg DT & & & & & $\begin{array}{l}-0.0414^{*} \\
(0.0200)\end{array}$ & $\begin{array}{l}-0.0231 \\
(0.0161)\end{array}$ \\
\hline Observations & 232,012 & 242,049 & 242,112 & 204,016 & 248,970 & 176,915 \\
\hline
\end{tabular}

The reported coefficients of the trust in government organizations are quantitatively and qualitatively very similar to those in Table 2 . We find a large, positive and statistically significant correlation between tax morale and trust in all five government organizations for the regression models in which they enter singularly, in columns (1) through (5). In fact, the effect size is larger than for the estimates in Table 2. The novel results in Table 3 include the effects of a positive and a negative democratic transition on tax morale and the interactive effects of trust in different government organizations on tax morale in periods of democratic transition. The event of a positive democratic transition has a null effect on the probability of reporting high tax morale across all specifications in Table 3. ${ }^{17}$ However, a negative transition does have a positive and statistically

\footnotetext{
17 Torgler (2003c, 2007b) finds survey respondents from a Central or Eastern European country to report an increased tax morale relative to respondents from former Soviet countries, perhaps reflecting that the former countries had been more successful in "controlling the decay of tax morale during the transformation process". Note that those findings implicitly confirm the absence of any (positive) improvements in tax morale in the transition to
} 
significant impact. In fact, the magnitude of the estimated effects is large enough to dominate the incremental effect of the interaction terms that has the opposite sign.

The estimated interaction terms reveal an interesting relationship between tax morale and trust in different government organizations in the wake of a positive democratic transition. The joint interpretation of the coefficient estimates in column (6) indicate that respondents with trust in the police or the courts during a period of either democratic transition are associated with lower tax morale than either those who lack trust during the transition or those who trust these organizations in periods of political stability. If trust in the police or the courts is an indication of respondents' preference for a strong rule of law, the negative effect on tax morale may be interpreted as a statement of protest to the likely social instability associated with periods of democratic transition.

\section{Conclusions}

In recent years, scholars have shifted their focus to ask what makes people willing to comply with taxes beyond the incentives provided by audit probabilities and potential fines which were emphasized in the classical Allingham and Sandmo (1972) model. Considerable research has now been conducted verifying the important role of tax morale in tax compliance behavior (Luttmer and Singhal, 2014). This in turn has led to asking the question of what shapes tax morale. In this paper we have argued that trust in government and therefore the willingness to comply with tax laws is affected by the way citizens are treated when interacting with government institutions in the regular delivery of public goods and services. The evidence available from other fields strongly supports the argument that trust plays a fundamental role in fostering cooperation, and 
thus provides independent support for the hypothesized mechanism for building tax morale. We empirically test the propositions that individuals who trust government are more likely to exhibit higher tax morale and that trust in the output organizations of government in particular is even more likely to increase tax morale. For the empirical analysis we use data from 92 countries covering the 1981-2014 period in six successive waves of the WVS. Our results suggest that tax morale is influenced by individual trust in government organizations; and, particularly so, by trust in output-side government organizations, the entities with which individuals are more likely to interact.

From a tax policy standpoint, the results in this paper are consistent with the recommendation in the tax compliance literature that building a relationship of trust and cooperation between taxpayers and tax authorities is necessary to elicit voluntary tax compliance (e.g. Braithwaite, 2003; Alm and Martinez-Vazquez, 2007). Furthermore, the results in this paper suggest the need to expand that recommendation to all the output organizations of government (and not only where taxpayers meet tax authorities). Finally, the positive influence of a negative democratic transition on tax morale highlights the importance of the "enforced compliance" channel of the slippery slope framework. Assuming that a negative democratic transition goes in tandem with a "cops and robbers" attitude towards taxpayers, our findings suggest that even this approach may still yield increased tax morale despite its limitations in comparison to the "service and clients" approach (Kirchler et al., 2008).

More generally, tax administration reform should be just one part of a broader reform in the public sector to instill trust in government. If individuals are at the mercy of government agents that demand bribes in exchange for goods and services individuals are entitled to get, impose sanctions that may not be appealed, trust in government is severely undermined and citizens cannot 
be expected to voluntarily comply with taxes. Building a professional and responsive bureaucracy may be a good step in building trust in government and in fellow citizens (Rothstein, 2000; Rothstein and Stolle, 2008). We find evidence of all those beneficial effects in this paper. 


\section{References}

Alesina, A., Giuliano, P., 2011. Preferences for redistribution. In: Jess Benhabib, J., Bisin, A., Jackson, M. O. (Eds.). Handbook of Social Economics, vol. 1. Amsterdam: North-Holland, 93-131.

Allingham, M.G., Sandmo, A., 1972. Income tax evasion: a theoretical analysis. Journal of Public Economics 1, 323-338.

Alm, J., 1999. Tax compliance and administration. Public Administration and Public Policy 72, 741-768.

Alm, J., Cherry, T., Jones, M., McKee, M., 2010. Taxpayer information assistance services and tax compliance behavior, Journal of Economic Psychology 31 (4), 577-586.

Alm, J., Jackson, B.R., McKee, M., 1993. Fiscal exchange, collective decision institutions, and tax compliance. Journal of Economic Behavior \& Organization 22 (3), 285-303.

Alm, J., Martinez-Vazquez, J., 2007. Tax morale and tax evasion in Latin America. International Center for Public Policy Working Paper Series, No. 0704, Andrew Young School of Policy Studies, Georgia State University.

Alm, J., McClelland, G.H., Schulze, W.D., 1999. Changing the social norm of tax compliance by voting. Kyklos 52 (2), 141-171.

Alm, J., Torgler, B., 2006. Culture differences and tax morale in the United States and in Europe. Journal of Economic Psychology 27 (2), 224-246.

Alm, J., Torgler, B., 2011. Do ethics matter? Tax compliance and morality. Journal of Business Ethics 101 (4), 635-651.

Becker, G.S., 1968. Crime and punishment: an economic approach. Journal of Political Economy, 76 (2), 169-217.

Bowles, S., 2008. Policies designed for self-interested citizens may undermine the moral sentiments: evidence from economic experiments. Science 320 (5883), 1605-1609.

Braithwaite, V., 2003. Tax system integrity and compliance: the democratic management of the tax system. In: Braithwaite, V. (Ed.). Taxing Democracy: Understanding Tax Avoidance and Evasion. Aldershot, England; Burlington, VT: Ashgate, 271-289.

Casal, S., Kogler, C., Mittone, L., Kirchler, E., 2016. Tax compliance depends on voice of taxpayers. Journal of Economic Psychology, 56, 141-150.

Citrin, J., 1974. Comment: The Political Relevance of Trust in Government. The American Political Science Review 68 (3), 973-988.

Chan, H.F., Supriyadi, M.W., Torgler, B., 2017. Trust and tax morale. In: Uslaner, E. M. (Ed.). The Oxford Handbook of Social and Political Trust, Oxford, UK: Oxford University Press.

Cummings, R.G., Martinez-Vazquez, J., McKee M., Torgler, B., 2009. Tax morale affects tax compliance: evidence from surveys and an artefactual field experiment. Journal of Economic Behavior \& Organization, 70 (3), 447-457

Cyan, M.R., Koumpias, A.M., Martinez-Vazquez, J., 2016. The determinants of tax morale in Pakistan. Journal of Asian Economics, 47, 23-34.

Cyan, M.R., Koumpias, A.M., Martinez-Vazquez, J., 2017. The effects of mass media campaigns on individual attitudes towards tax compliance; quasi-experimental evidence from survey data in Pakistan. Journal of Behavioral and Experimental Economics, 70, 10-22. 
Dalton, R.J., 1996. Political cleavages, issues, and electoral choice. In: LeDuc, L., Niemi, R.G., Norris, P. (Eds.). Comparing democracies: elections and voting in global perspectives, Thousand Oaks, CA: Sage Publications, 319-342.

Daude, C., Gutierrez, H., \& Melguizo, A., 2013. What drives tax morale? A focus on emerging economies. Review of Public Economics, 207 (4), 9-40.

De Cremer, D., Tyler, T.R., 2007. The effects of trust in authority and procedural fairness on cooperation. Journal of Applied Psychology 92 (3), 639.

Doerrenberg, P., Peichl, A., 2013. Progressive taxation and tax morale. Public Choice, 155 (3-4), 293-316.

Doerrenberg, P., \& Peichl, A. (2018). Tax Morale and the Role of Social Norms and Reciprocity. Evidence from a Randomized Survey Experiment.

Donnelly, M., Pop-Eleches, G., 2018. Income measures in cross-national surveys: problems and solutions. Political Science Research and Methods, 6 (2), 355-363.

Drogalas, G., Anagnostopoulou, E., Pazarskis, M., Petkopoulos, D., 2018. Tax Ethics and Tax Evasion, Evidence from Greece. Theoretical Economics Letters, 8, 1018-1027.

Dulleck, U., Fooken, J., Newton, C., Ristl, A., Schaffner, M., Torgler, B., 2016. Tax compliance and psychic costs: behavioral experimental evidence using a physiological marker. Journal of Public Economics 134 (C), 9-18.

Feld, L.P., Frey, B.S., 2002. Trust breeds trust: how taxpayers are treated. Economics of Governance 3 (2) 87-99.

Frey, B.S., Feld, L.P., 2002. Deterrence and morale in taxation: An empirical analysis.

Feld, L.P., Frey, B.S., 2007. Tax compliance as the result of a psychological tax contract: the role of incentives and responsive regulation. Law \& Policy 29 (1), 102-120.

Feld, L.P., Tyran, J.R., 2002. Tax evasion and voting: an experimental analysis. Kyklos 55 (2), 197-222.

Filippin, A., Fiorio, C., Viviano, E., 2013. The effect of tax enforcement on tax morale. European Journal of Political Economy 32 (C), 320-331.

Frey, B.S., Benz, M., Stutzer, A., 2004. Introducing procedural utility: Not only what, but also how matters. Journal of Institutional and Theoretical Economics 160 (3), 377-401.

Frey, B.S., Stutzer, A., 2005. Beyond outcomes: measuring procedural utility. Oxford Economic Papers 57 (1), 90-111.

Gangl, K., Muehlbacher, S., de Groot, M., Goslinga, S., Hofmann, E., Kogler, C., Antonides, G., Kirchler, E., 2013. "How can I help you?" Perceived service orientation of tax authorities and tax compliance. FinanzArchiv: Public Finance Analysis, 69(4), 487-510.

Halla, M., 2011. The link between the intrinsic motivation to comply and compliance behavior: a critical appraisal of existing evidence. In: Schneider, F. (Ed.). Handbook of the Shadow Economy, Edward Elgar Publishing, 375

Halla, M., 2012. Tax morale and compliance behavior: First evidence on a causal link. The BE Journal of Economic Analysis \& Policy, 12 (1), 1-25.

Hug, S., Spörri, F., 2011. Referendums, trust, and tax evasion. European Journal of Political Economy 27 (1), 120-131.

Inglehart, R., 2003. How solid is mass support for democracy: and how can we measure it? PS: Political Science and Politics 36 (1), 51-57. 
Inglehart, R., Haerpfer, C., Moreno, A., Welzel, C., Kizilova, K., Diez-Medrano, J., Lagos, M., Norris, P., Ponarin, E., Puranen, B., 2014. World Values Survey: All Rounds - CountryPooled Datafile 1981-2014. Madrid: JD Systems Institute. Version http://www.worldvaluessurvey.org/WVSDocumentationWVL

Konrad, K.A., Qari, S., 2012. The last refuge of a scoundrel? Patriotism and tax compliance, Economica 79 (315), 516-533.

Koumpias, A. M., Martinez-Vazquez, J., 2019. The impact of media campaigns on tax filing: quasi experimental evidence from Pakistan. Journal of Asian Economics, https://doi.org/10.1016/j.asieco.2019.05.002

Lago-Peñas, I., Lago-Peñas, S., 2010. The determinants of tax morale in comparative perspective: Evidence from European countries. European Journal of Political Economy 26 (4), 441-453.

Levi, M., 1998. A state of trust. In: Braithwaite, V., Levi, M., (Eds.). Trust and Governance, New York: Russell Sage Foundation, 77-101.

Levi, M., Stoker. L., 2000. Political trust and trustworthiness. Annual Review of Political Science 3 (1), 475-507.

Linde, J., 2012. Why feed the hand that bites you? Perceptions of procedural fairness and system support in post-communist democracies. European Journal of Political Research 51 (3), 410-434.

Litina, A., Palivos, T., 2016. Corruption, tax evasion and social values. Journal of Economic Behavior \& Organization 124, 164-177.

Liu, X., 2014. Fitting stereotype logistic regression models for ordinal response variables in educational research (Stata). Journal of Modern Applied Statistical Methods, 13 (2), 31.

Luttmer, E., Singhal, M., 2014. Tax morale. Journal of Economic Perspectives 28 (4), 149-168.

Madison, J., 1788. The federalist No. 51. The structure of the government must furnish the proper checks and balances between the different departments. Independent Journal, http://www.constitution.org/fed/federa51.htm.

Martinez-Vazquez, J., Torgler. B., 2009. The evolution of tax morale in modern Spain. Journal of Economic Issues 43 (1), 1-28.

Myles, G., Naylor, R., 1996. A model of tax evasion with group conformity and social customs, European Journal of Political Economy 12 (1), 49-66.

North, D. C., 1994. Economic performance through time. The American Economic Review 84 (3), 359-368.

Orviska, M., Hudson, J., 2003. Tax evasion, civic duty and the law abiding citizen. European Journal of Political Economy 19 (1), 83-102

Ostrom, E., 1998. A behavioral approach to the rational choice theory of collective action: Presidential address, American Political Science Association, 1997. American Political Science Review 92 (1), 1-22.

Ostrom, E., 2000. Collective action and the evolution of social norms. Journal of Economic Perspectives 14 (3), 137-158.

Pommerehne, W.W., Weck-Hannemann, H., 1996. Tax rates, tax administration and income tax evasion in Switzerland. Public Choice 88 (1-2), 161-170.

Rohrschneider, R., 2005. Institutional quality and perceptions of representation in advanced industrial democracies. Comparative Political Studies 38 (7), 850-874. 
Rothstein, B., 2000. Trust, social dilemmas and collective memories. Journal of Theoretical Politics 12 (4), 477-501.

Rothstein, B., 2005. Social traps and the problem of trust: Cambridge University Press.

Rothstein, B., 2009. Creating political legitimacy: electoral democracy versus quality of government. American Behavioral Scientist 53 (3), 311-330.

Rothstein, B., Stolle. D., 2008. The state and social capital: an institutional theory of generalized trust. Comparative Politics 40 (4), 441-459.

Rothstein, B., Teorell. J., 2008. What is quality of government? a theory of impartial government institutions. Governance 21 (2), 165-190.

Rodriguez-Justicia, D., Theilen, B., 2018. Education and tax morale. Journal of Economic Psychology, 64, 18-48.

Schnellenbach, J., 2006. Tax morale and the taming of leviathan. Constitutional Political Economy 17 (2), 117-132.

Scholz, J.T., Lubell M., 1998a. Adaptive political attitudes: duty, trust, and fear as monitors of tax policy. American Journal of Political Science 42(3), 903.

Scholz, J.T., Lubell M., 1998b. Trust and taxpaying: testing the heuristic approach to collective action. American Journal of Political Science 42(2), 398.

Scholz, J.T., Pinney N., 1995. Duty, fear, and tax compliance: the heuristic basis of citizenship behavior. American Journal of Political Science 39(2), 490-512.

Slemrod, J., 2003. Trust in public finance. In: Cnossen, S., Sinn, H.W. (Eds.). Public Finance and Public Policy in the New Century, Cambridge, MA: MIT Press, 49-88.

Slemrod, J., 2007. Cheating ourselves: the economics of tax evasion. The Journal of Economic Perspectives 21 (1), 25-48.

Sunshine, J., Tyler, T. R., 2003. The role of procedural justice and legitimacy in shaping public support for policing. Law \& Society Review 37 (3), 513-548.

Torgler, B., 2002a. Does culture matter? Tax morale in an East West-German comparison. FinanzArchiv/Public Finance Analysis 59 (4), 504-528.

Torgler, B., 2002b. Speaking to theorists and searching for facts: tax morale and tax compliance in experiments. Journal of Economic Surveys 16 (5), 657-683.

Torgler, B., 2003a. Tax morale and institutions. SSRN 663686.

Torgler, B., 2003b. Tax morale, rule-governed behavior and trust. Constitutional Political Economy 14 (2), 119-140.

Torgler, B., 2003c. Tax morale in transition countries. Post-Communist Economies 15 (3), 357.

Torgler, B., 2004a. Tax morale, trust and corruption: empirical evidence from transition countries. Center for Research in Economics, Management and the Arts (CREMA), Working Paper 5, 3-24.

Torgler, B., 2004b. Cross-culture comparison of tax morale and tax compliance: evidence from Costa Rica and Switzerland. International Journal of Comparative Sociology 45 (1-2), 1743.

Torgler, B., 2004c. Tax morale in Asian countries. Journal of Asian Economics 15 (2), 237-266.

Torgler, B., 2005a. Tax morale and direct democracy. European Journal of Political Economy 21 (2), 525-31.

Torgler, B., 2005b. Tax morale in Latin America. Public Choice 122 (1/2), 133-157. 
Torgler, B., 2006. The importance of faith: tax morale and religiosity. Journal of Economic Behavior \& Organization 61 (1), 81-109.

Torgler, B., 2007a. Tax compliance and tax morale: a theoretical and empirical analysis. Edward Elgar Publishing.

Torgler, B., 2007b. Tax morale in Central and Eastern European countries. In: Hayoz, N., Hug, S. (Eds.). Tax Evasion, Trust and State Capacities, Peter Lang, 155-186.

Torgler, B., Murphy, K., 2005. Tax morale in Australia: what shapes it and has it changed over time? Centre for Tax System Integrity.

Torgler, B., Schneider, F., 2004. Does culture influence tax morale? evidence from different European countries. Wirtschaftswiss. Zentrum der Univ.

Torgler, B., Schneider. F., 2007. What shapes attitudes toward paying taxes? evidence from multicultural European countries. Social Science Quarterly 88 (2), 443-470.

Traxler, C., 2010. Social norms and conditional cooperative taxpayers. European Journal of Political Economy, 26 (1), 89-103.

Wahl, I., Muehlbacher, S., and Kirchler, E., 2010. The impact of voting on tax payments. Kyklos 63 (1), 144-58. 


\section{Appendix A. Figures}

Figure A.1: WVS 10-point Tax Morale Response Histogram

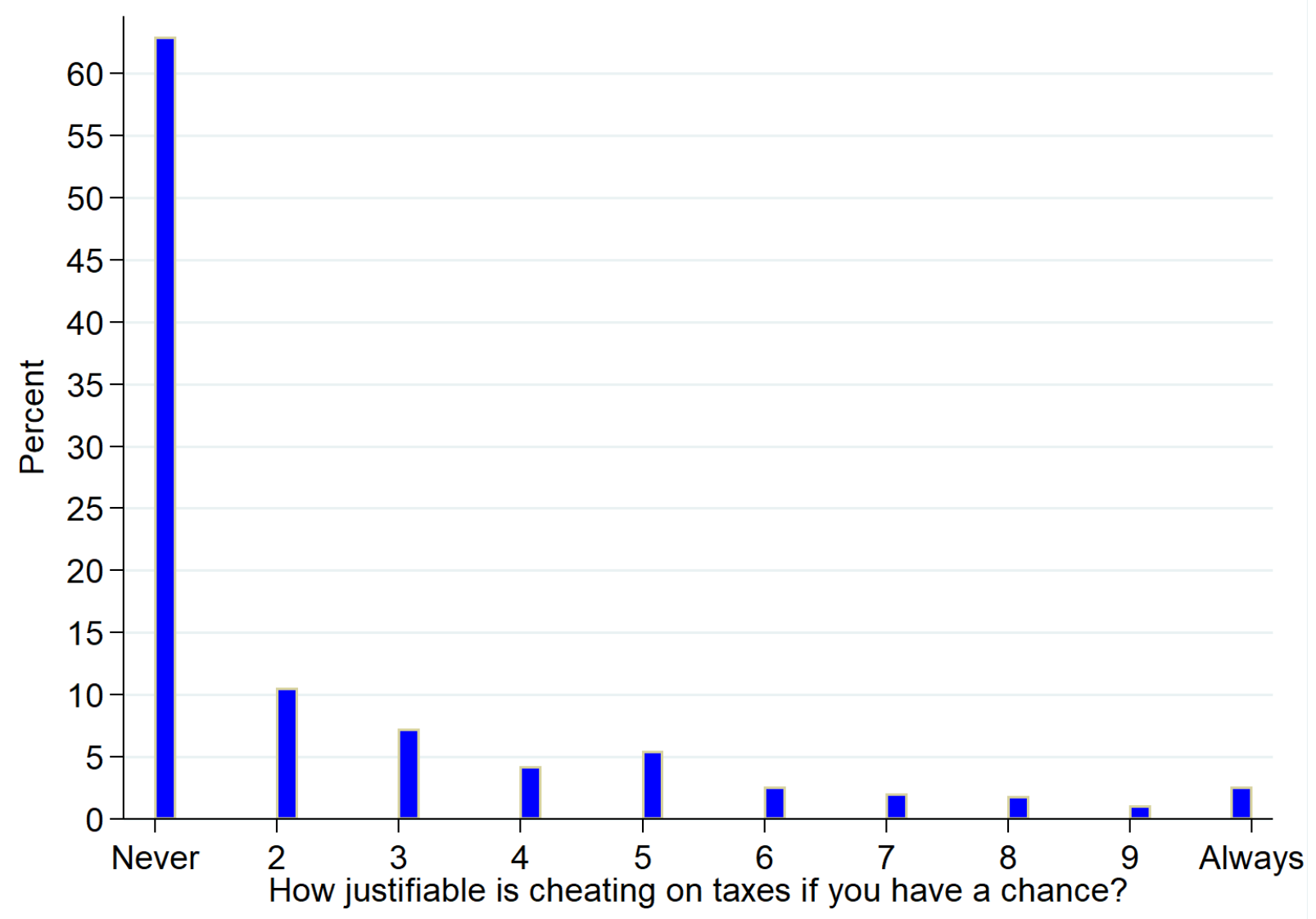




\section{Appendix B. Tables}

Table B.1: Input-side and Output-side Organizations of the Government

\begin{tabular}{ll}
\hline \hline Input-Side & Output-Side \\
National Government & Civil Services (e.g. tax administration) \\
Acting Parliament & Justice and Courts \\
& Police
\end{tabular}

Table B.2: Freedom House Country Ratings

\begin{tabular}{|c|c|c|c|}
\hline \multicolumn{4}{|c|}{ Free Countries } \\
\hline Andorra & France & Netherlands & South Korea (1989-2014) \\
\hline Argentina & Germany & New Zealand & Spain \\
\hline Australia & Ghana & Norway & Sweden \\
\hline Brazil & Hungary & Peru (1999-2004, 2010-14) & Switzerland \\
\hline Bulgaria & India (1999-2014) & Philippines (1999-2004) & Taiwan \\
\hline Canada & Indonesia (2005-09) & Poland & Trinidad and Tobago \\
\hline Chile & Italy & Romania & UK \\
\hline Cyprus & Japan & Serbia & Ukraine (2005-09) \\
\hline Czech Republic & Latvia & Serbia \& Montenegro & United States \\
\hline East Germany & Lithuania & Slovakia & Uruguay \\
\hline Estonia & Mali & Slovenia & Venezuela (1994-98) \\
\hline Finland & Mexico (1999-2009) & South Africa (1994-2014) & West Germany \\
\hline \multicolumn{4}{|c|}{ Partially Free Countries } \\
\hline Albania & El Salvador & $\begin{array}{l}\text { Mexico (1981-1998, 2010- } \\
\text { 2014) }\end{array}$ & Tanzania \\
\hline Argentina (1981-84) & Ethiopia & Moldova & Thailand \\
\hline Armenia & Georgia & Morocco & Tunisia \\
\hline Bangladesh & Guatemala & Nigeria (1989-98, 2010-14) & Turkey \\
\hline Belarus (1989-93) & India (1989-98) & North Macedonia & Uganda \\
\hline Bosnia & Indonesia (1999-2004) & Pakistan (2010-14) & $\begin{array}{l}\text { Ukraine }(1994-98,2010- \\
14)\end{array}$ \\
\hline Burkina Faso & Jordan (1999-2009) & Philippines (2010-14) & Venezuela (1999-2004) \\
\hline Colombia & Kuwait & Russia (1989-98) & \\
\hline Croatia & Kyrgyzstan (2010-14) & Singapore & \\
\hline Dominican Republic & Lebanon & South Africa (1981-93) & \\
\hline Ecuador & Malaysia & South Korea (1981-84) & \\
\hline \multicolumn{4}{|c|}{ Not Free Countries } \\
\hline Algeria & Iran & Libya & Uzbekistan \\
\hline Azerbaijan & Iraq & Nigeria (1994-98) & Vietnam \\
\hline $\begin{array}{l}\text { Belarus (1994-1998, } \\
\text { 2010-14) }\end{array}$ & Jordan (2010-14) & Pakistan (1999-2004) & Yemen \\
\hline China & Kazakhstan & Russia (2005-14) & Zimbabwe \\
\hline Egypt & $\begin{array}{l}\text { Kyrgyzstan (1999- } \\
2004)\end{array}$ & Rwanda & \\
\hline
\end{tabular}

